\title{
Microbiological Quality Assessment of Indoor Air of a Private University in Benin City, Nigeria.
}

\author{
Amengialue, O. O. ${ }^{1}$, Okwu, G. I' ${ }^{2}$, ,Oladimeji, O. R. ${ }^{1}$, Iwuchukwu, A. A. \\ ${ }^{I}$ Department of Biological Sciences, College of Natural and Applied Sciences, Wellspring University, \\ P.M.B.1230, Benin City, Edo State, Nigeria. \\ ${ }^{2}$ Department of Microbiology, Faculty of Natural Sciences, Ambrose Alli University, P.M.B. 14, Ekpoma, Edo \\ State, Nigeria.
}

\begin{abstract}
The evaluation of microorganisms present in indoors has become necessary, as how safe the air in our surrounding environment where we spent time is fundamental to our wellbeing. Hence, this study was aimed at assessing the indoor air quality of a private university in Benin City using the settle plate air sampling technique with sampling done morning and evening, once in succession for two weeks. The estimated concentration range of bacterial aerosols in the indoor environments was $7-440 \mathrm{cfu} / \mathrm{m}^{3}$ and $4-90 \mathrm{cfu} / \mathrm{m}^{3} \mathrm{for}$ week 1 morning and evening sampling respectively, and $72-180 \mathrm{cfu} / \mathrm{m}^{3}$ and $8-75 \mathrm{cfu} / \mathrm{m}^{3}$ for week 2 morning and evening sampling respectively. Also, the fungal aerosols concentration range recorded $11-45 \mathrm{cfu} / \mathrm{m}^{3}$ and 3 $-10 \mathrm{cfu} / \mathrm{m}^{3}$ for week 1 morning and evening sampling respectively, and $1-57 \mathrm{cfu} / \mathrm{m}^{3}$ and $5-45 \mathrm{cfu} / \mathrm{m}^{3}$ for week 2 morning and evening sampling respectively. Microbial isolates characterized were Micrococcus luteus, Klebsiella pneumonia, Micrococcus sp., Staphylococcus epidermidis, Serratiamarcensces, Streptococcus pyogenes, Bacillus subtilis, Pseudomonas aeruginosa, Staphylococcus aureus, Proteus mirabilis and Escherichia coli, Neurospora sp., Rhizopus sp., Penicillium sp., Candida sp., Fusarium sp. Aspergillusniger, Alternaria sp., Aspergillusfumigatus, Cladosporiumcladosporoides. Among the microbial isolates, Aspergilusniger had the highest percentage frequency (29\%) while Sarretiamarcensces and Candida sp. had the least percentage frequency (4\%) each. These isolates are considered potential candidates of 'sick building' syndromes. Thus, attention must be given to control environmental factors which favour microbial growth and multiplication in indoor environment for health safety.
\end{abstract}

Keywords: Indoor air, sample, morning, evening, Staphylococcus aureus

\section{Introduction}

Air, as a non-renewable resource, supplies us with the energy production requirement, oxygen which is essential for our bodies to live.Pollution of the air is the introduction of chemicals, particulate matter or biological materials into the atmosphere, capable of causing discomfort, disease or death to humans, damage to other living organisms including food crops. Since air is an important medium for the spread of infectious and allergic triggers which can result to undesirable effects on human beings, the control of the microbial charge became an important key to define the environmental quality of ambient media surrounding wide human populations which are largely exposed to indoor air during their daily activities (Soto et al., 2009). Indoor air quality (IAQ), as the name implies, is a term used to assess the quality of the air in indoor environment like offices and other building environments.In a normal indoor environment, the quantity of microorganisms should be significantly lower than outdoor levels. Possible sources of biological contamination of indoor air include: people, organic dust, various materials stored in the buildings, and the air inflowing from the ventilation and air conditioning systems (Kalwasińskaet. al., 2012).

Depending on the amount of viscosity, temperature, lighting, and food available, different species may become dominant (Dumala and Dudzinska, 2013). The presence of bacteria and fungi in indoor air pose a serious problem from the point of view of health protection and environmental engineering. Dust, a good vehicle of airborne contamination may arise from human activities such as sweeping, movements, waving of handkerchief and bed making. Sneezing has been described as the most vigorous mechanism of generating millions of droplet into the environment with the larger falling to the ground and smaller ones evaporate and remain suspended as nuclei (Awosikaet. al., 2012). Although pathogenic species are rather scarce in the air, some relevant microorganisms travel by aerial transmission and are involved in serious processes causing pneumonia and other diseases. Aerial fungi are much more important than bacteria as agents for allergic diseases. Air sampling of microorganisms is a popular method of conducting microbial examinations, as it allows a direct toxicological evaluation.The problem of environmental pollution is enormous and various attempts have been made to establish facilities for its control and regulation in various parts of the world.

Results have shown from various studies that microbial characterisation of different indoor air environments differ greatly in time, season, location and ventilation. According to (Udochukwuet. al., 2015); 
Microbiological Quality Assessment Of Indoor Air Of A Private University In Benin City, Nigeria.

major bacterial and fungal strains found in the University of Port Harcourt dormitories include Micrococcus spp., Enterococcus spp., Staphylococcus spp., Serratia spp., Bacillus sp.and Kiebsiella spp. Fungi: Aspergillus sp.,Fusarium sp., Altenaria sp., Penicillium sp. and Cladosporium sp. (Stryjakowska-Sekulskaet al. 2007) had also recorded similar results of bacterial and fungal load in university rooms in Poland, he also reported that Escherichia genus was dominant in toilet indoor air and some species of Cladosporium, Alternaria, Mucor, Rhizopus and Epicoccumprevailed in a canteen and a corridor. This is mainly affected by the inflow of students in a new academic session with an inflow of different students from different backgrounds with different internal microbial characteristics resulting in the release of such through sneezing, coughing or yawning. This current study will try to develop a trend in microbial load in university rooms.

\section{Study Site}

\section{Materials And Method}

This study was carried out in Wellspring University, Benin City, Nigeria. Wellspringis a private tertiary institution, licenced and approved by the Federal Government of Nigeria. The institution is located in Benin City, Edo State, in the Southern region of Nigeria. Ten (10) sampling locations in the university were used in this study and they include Sickbay, Library, Administrative block, Male hostel, Female hostel, Lecture hall 1 and 2, Staff office, Canteen and Laboratory.

\section{Sampling Procedure}

Samples were taken in the school environments. Passive monitoring, using the settle plate method was done by exposing the petri dishes containing culture media at the different sampling location to be examined in the school. Sampling was done in the morning at 8:00am and evening at 4:00pm. Air samples were collected once a week for two weeks consecutively in the month of July at ten (10) sampling locations for bacterial and fungal; giving a total of 80 samples collected. The plates containing nutrient agar (NA) and potato dextrose agar (PDA) were used for the isolation of bacterial and fungal isolates respectively. An antifungal agent (Griseofulvin) was impregnated into the nutrient agar medium for the inhibition of fungi while antibiotic (Chloramphenicol) was impregnated into the potato dextrose agar medium for the inhibition of bacteria growth. Each plate was exposed on a table above ground level for a period of 30 minutesfor air sampling. The bacterial culture plates were incubated at a temperature of $37^{\circ} \mathrm{C}$ for 48 hours in an incubator while the fungal culture plates were left on the laboratory working bench at room temperature $\left(20-28^{0} \mathrm{C}\right)$ for $5-7$ days.

\section{Microbiological Examination}

After incubation, all the nutrient agar plates incubated at $37^{\circ} \mathrm{C}$ for 48 hours were observed, and total number of bacterial colony forming units per cubic meter were counted and recorded. The colonial morphology of the colonies formed was noted; distinctand identical colonies were sub-cultured and incubated at $37^{\circ} \mathrm{C}$ for 24 hours and stored for identification and characterizationaccording to Bergey's Manual of Systematic Bacteriology (Sneathet al., 1986.) The fungal colonies were enumerated after which morphological and colonial characteristics of each colony was identified according to the manual of Barnet and Hunter 1972. The identification of fungal isolates was done according to standard methods (Chessbrough, 1991).

\section{Results}

Results below revealed the microbiological quality of the sampled indoor air from ten (10) different location sites in the study location. Tables 1 - 4 revealed the microbial load of the indoor air sampled while tables 5 and 6 showed the different microbial species of the sampled indoor air and their occurrence. Also, Figures $1-8$ showed the percentage frequency of the microbial speciesas isolated from the indoor air sampled.

Table 1: Week 1 Concentration of bacteria isolates of sampled indoor air

\begin{tabular}{|lcc|}
\hline SAMPLING SITE & \multicolumn{2}{c}{ SAMPLING TIME } \\
8.00am & $\mathbf{4 . 0 0 p m}$ & \\
\hline Sickbay & 80 & 25 \\
\hline Library & 14 & 12 \\
\hline Admin block & 24 & 15 \\
\hline Female hostel & 440 & 90 \\
\hline Male hostel & 23 & 35 \\
\hline Lecture hall 1 & 7 & 4 \\
\hline Lecture hall 2 & 10 & 5 \\
\hline Office & 17 & 12 \\
\hline Canteen & 14 & 15 \\
\hline Laboratory & 20 & 9
\end{tabular}


Table 2: Week 1 concentration of fungi isolates of sampled indoor air SAMPLING SITE

\begin{tabular}{|ccc} 
SAMPLING TIME & $\mathbf{4 . 0 0 p m}$ \\
\hline 8.00am & & \\
& 30 & 6 \\
14 & 5 \\
35 & 10 \\
45 & 3 \\
11 & 6 \\
27 & 10 \\
22 & 5 \\
25 & 3 \\
20 & 4 \\
30 &
\end{tabular}

Table 3: Week 2 concentration of bacteria isolates of sampled indoor air

\begin{tabular}{l} 
SAMPLING SITE \\
\hline Sickbay \\
\hline Library \\
\hline Admin block \\
\hline Female hostel \\
\hline Male hostel \\
\hline Lecture hall 1 \\
\hline Lecture hall 2 \\
\hline Office \\
\hline Canteen \\
\hline Laboratory
\end{tabular}
SAMPLING TIME

8.00am

\begin{tabular}{|cc} 
& $\mathbf{4 . 0 0 p m}$ \\
100 & 40 \\
100 & 37 \\
76 & 33 \\
180 & 75 \\
105 & 65 \\
86 & 39 \\
93 & 8 \\
93 & 11 \\
72 & 25 \\
73 & 42 \\
\hline
\end{tabular}

Table 4: Week 2 concentration of fungi isolates of sampled indoor air

\begin{tabular}{l}
\hline SAMPLING SITE \\
\hline Sickbay \\
\hline Library \\
\hline Admin block \\
\hline Female hostel \\
\hline Male hostel \\
\hline Lecture hall 1 \\
\hline Lecture hall 2 \\
\hline Office \\
\hline Canteen \\
\hline Laboratory \\
\hline
\end{tabular}
SAMPLING TIME 8.00am $4.00 \mathrm{pm}$

$\begin{array}{cc}21 & 26 \\ 23 & 18 \\ 53 & 27 \\ 57 & 23 \\ 1 & 17 \\ 48 & 30 \\ 52 & 45 \\ 41 & 5 \\ 50 & 32 \\ 45 & 26\end{array}$

Table 5: Bacteria isolates occurrence in indoor air sample

\begin{tabular}{|l|l|l|l|l|l|l|l|l|l|l|}
\hline \multirow{2}{*}{ BACTERIA ISOLATES } & \multicolumn{9}{|c|}{ SAMPLE SITES } \\
\cline { 2 - 13 } & $\mathrm{A}$ & $\mathrm{B}$ & $\mathrm{C}$ & $\mathrm{D}$ & $\mathrm{E}$ & $\mathrm{F}$ & $\mathrm{G}$ & $\mathrm{H}$ & $\mathrm{I}$ & $\mathrm{J}$ \\
\hline Micrococcus luteus & + & + & + & + & + & - & + & + & + & + \\
\hline Klebsiella pneumonia & + & + & - & + & + & + & + & - & - & - \\
\hline Micrococcus sp. & + & + & + & + & + & + & + & + & + & + \\
\hline Staphylococcus epidermidis & - & - & - & + & + & - & - & - & - & - \\
\hline Serratiamarcensces & - & - & - & + & - & - & + & - & + & + \\
\hline Streptococcus pyogenes & + & + & + & + & + & + & + & + & + & - \\
\hline Bacillus subtilis & + & + & + & + & + & + & + & + & + & + \\
\hline Staphylococcusaureus & + & + & + & + & + & + & + & + & + & + \\
\hline Proteusmirabilis & - & - & - & - & + & - & + & - & - & - \\
\hline Escherichiacoli & + & + & + & + & + & - & + & - & - & - \\
\hline Pseudomonas aeruginosa & - & - & - & + & - & - & - & - & - & - \\
\hline
\end{tabular}

KEY: $\mathrm{A}=$ Sickbay, $\mathrm{B}=$ Library, $\mathrm{C}=$ Admin Block, $\mathrm{D}=$ Female hostel, $\mathrm{E}=$ Male hostel, $\mathrm{F}=$ Lecture hall I, G=Lecture hall II, H=Office, I=Canteen, J=Laboratory, + means present, - means absent 
Microbiological Quality Assessment Of Indoor Air Of A Private University In Benin City, Nigeria.

Table 6: Fungi isolates occurrence in indoor air sample

\begin{tabular}{|c|c|c|c|c|c|c|c|c|c|c|}
\hline \multirow[t]{2}{*}{ FUNGI ISOLATES } & \multicolumn{10}{|c|}{ SAMPLE SITES } \\
\hline & $\mathrm{A}$ & $\mathrm{B}$ & $\mathrm{C}$ & $\mathrm{D}$ & $E$ & $\mathrm{~F}$ & $\bar{G}$ & $\mathrm{H}$ & $\mathrm{I}$ & $\bar{J}$ \\
\hline Aspergillus fumigates & + & - & - & - & - & + & + & - & - & + \\
\hline Cladosporiumcladosporoides & - & - & + & + & - & - & - & + & + & + \\
\hline Neurospora sp. & - & + & - & + & + & + & - & - & - & + \\
\hline Penicillium sp. & + & + & + & + & - & + & - & + & + & + \\
\hline Rhizopus sp. & + & + & - & + & + & - & + & - & - & + \\
\hline Alternaria sp. & + & + & + & + & + & + & + & + & - & - \\
\hline Aspergillusniger & + & + & + & + & - & - & + & - & - & + \\
\hline Candida sp. & + & - & - & - & + & - & - & - & + & + \\
\hline Fusarium sp. & + & - & - & + & - & + & - & - & - & - \\
\hline
\end{tabular}

KEY: A= Sickbay, B=Library, $\mathrm{C}=$ Admin Block, $\mathrm{D}=$ Female hostel, E=Male hostel, $\mathrm{F}=$ Lecture hall I, $\mathrm{G}=$ Lecture hall II, $\mathrm{H}=$ Office, I=Canteen, $\mathrm{J}=$ Laboratory, + means present, - means absent

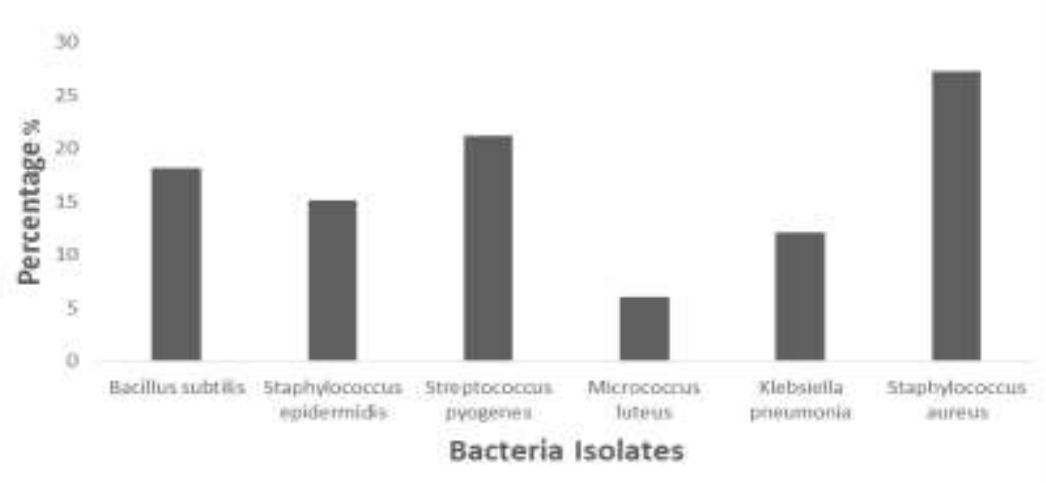

Figure 1: Percentage frequency of bacterial isolates in week 1 morning samples

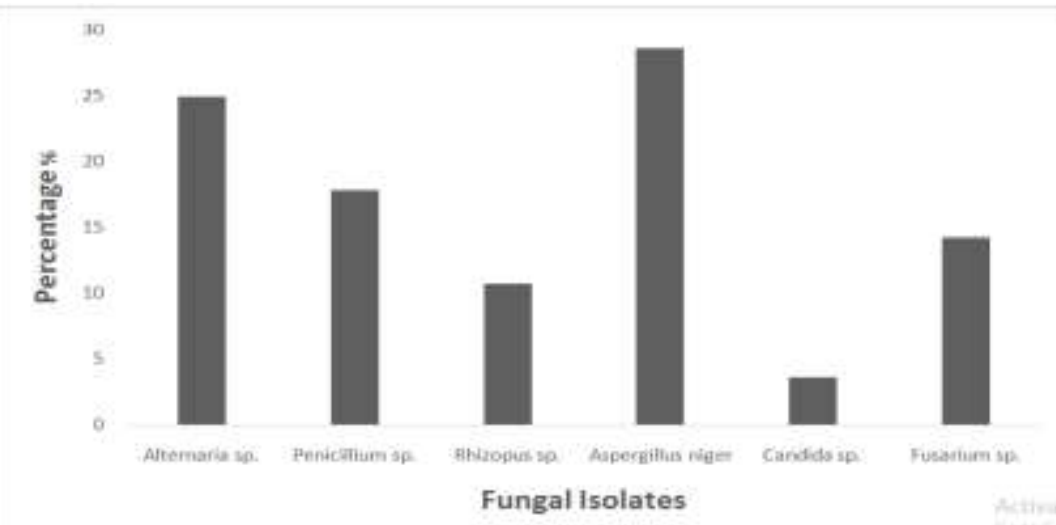

Figure 2: Percentage frequency of fungal isolates in week 1 morning samples

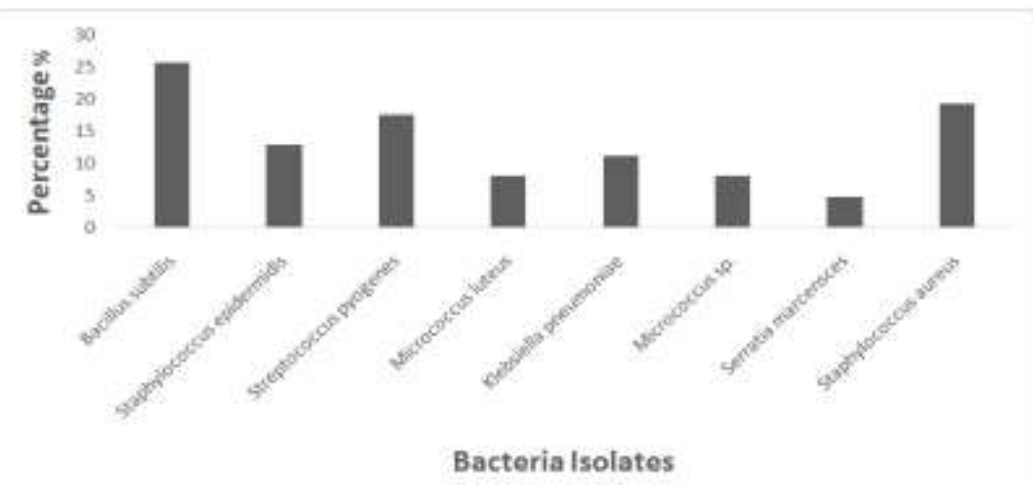

Figure 3: Percentage frequency of bacterial isolates in week 1 evening samples 


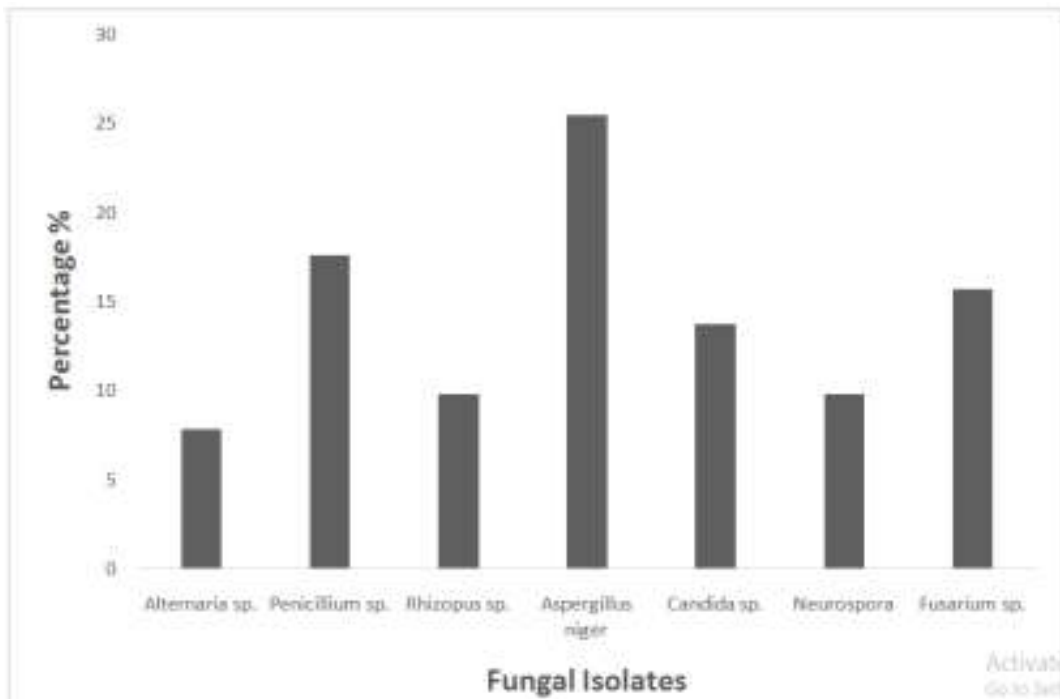

Figure 4: Percentage frequency of fungal isolates in week 1 evening samples

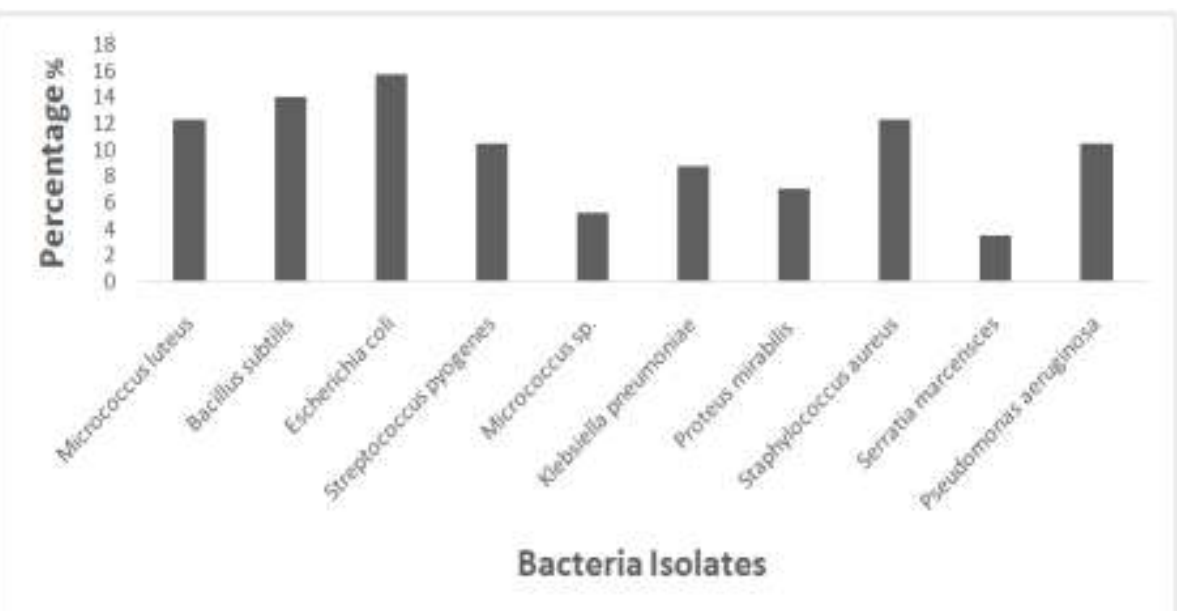

Figure 5: Percentage frequency of bacterial isolates in week 2 morning samples

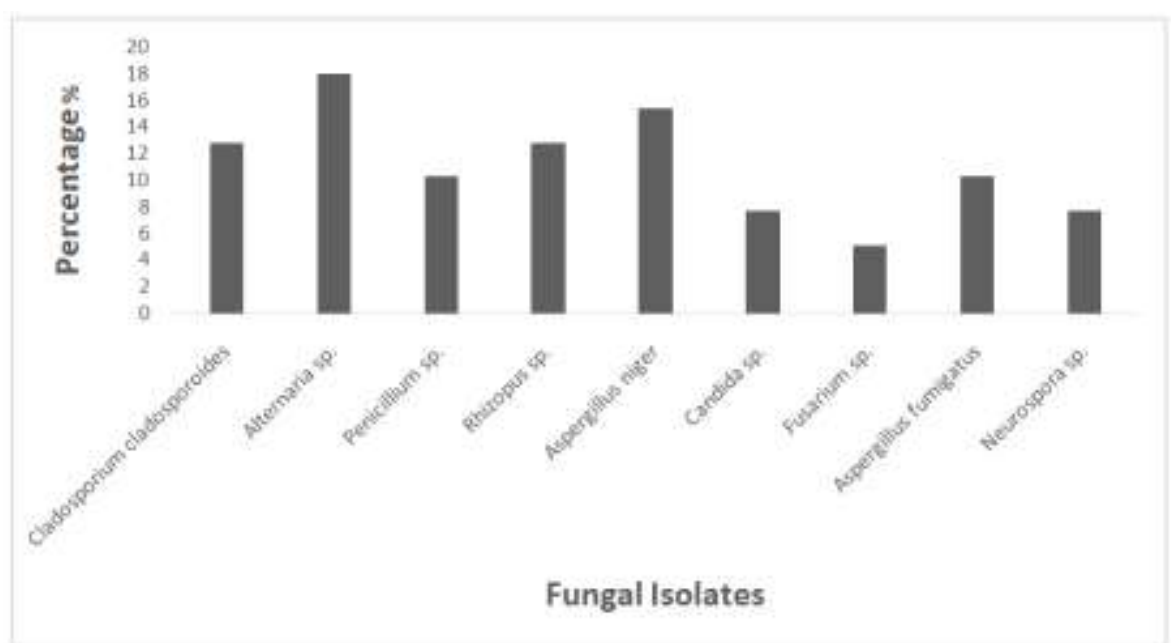

Figure 6: Percentage frequency of fungal isolates in week 2 morning samples 


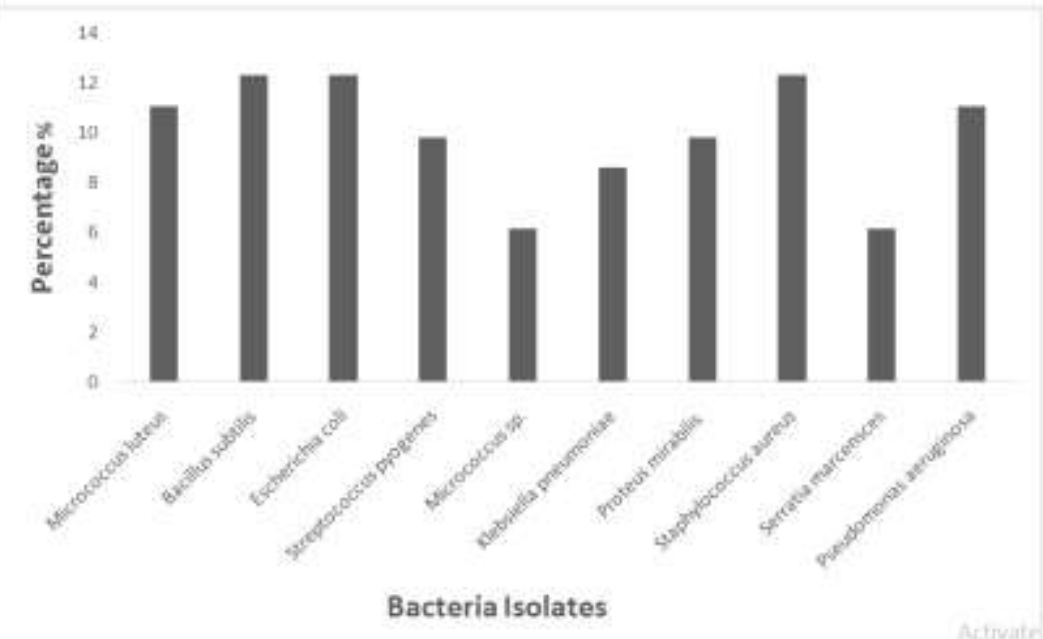

Figure 7: Percentage frequency of bacteria isolates in week 2 evening samples

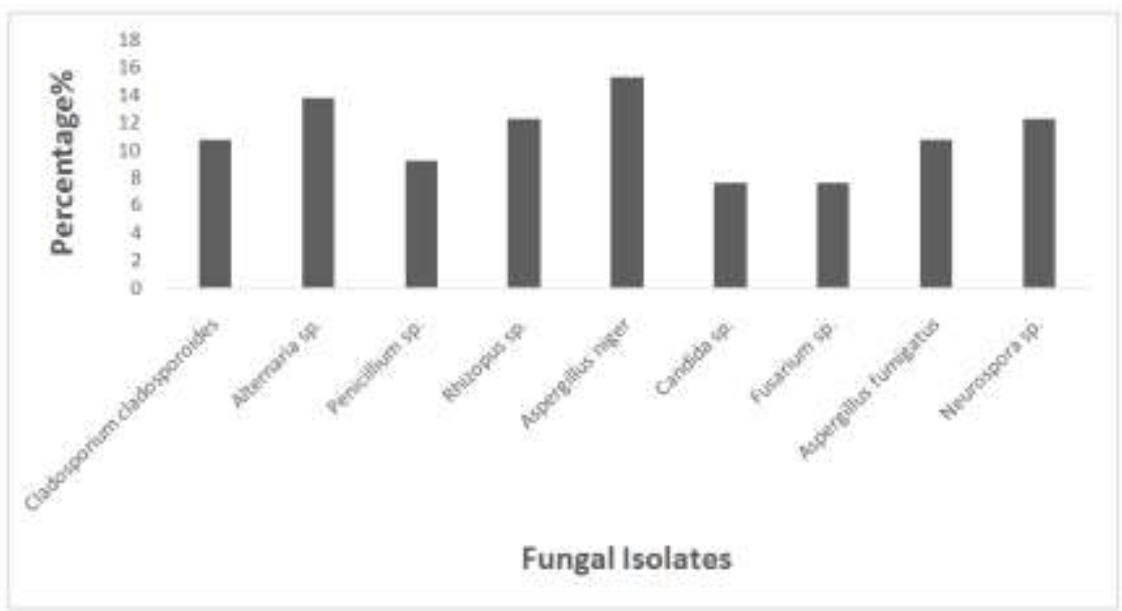

Figure 8: Percentage frequency of fungal isolates in week 2 evening samples

\section{Discussion}

Microbiological quality assessment of indoor air study is one of the most vital investigations to determine the microbial indoor air pollution. The information on the indoor microbial concentrations of airborne bacteria and fungi is necessary both to estimate the health hazards and to create standard for indoor air quality control. The concentrations of bacteria and fungi aerosols in the indoor air environment as sampled in this research work carried out in Wellspring University, estimated with the use of settle plate method ranged between $7-440 \mathrm{cfu} / \mathrm{m}^{3}$ (colony forming unit per cubic metre) and $11-45 \mathrm{cfu} / \mathrm{m}^{3}$ for bacteria and fungi respectively for week 1 morning sample; $4-90 \mathrm{cfu} / \mathrm{m}^{3}$ and $3-10 \mathrm{cfu} / \mathrm{m}^{3}$ for bacteria and fungi respectively for week 1 evening sample; $72-180 \mathrm{cfu} / \mathrm{m}^{3}$ and $1-57 \mathrm{cfu} / \mathrm{m}^{3}$ for bacteria and fungirespectively for week 2 morning sample; and $8-75 \mathrm{cfu} / \mathrm{m}^{3}$ and $5-45 \mathrm{cfu} / \mathrm{m}^{3}$ for bacteria and fungi respectively for week 2 evening sample. There was variation in concentration of bacteria and fungi across the various sample sites as hostels generally recorded the highest count while office recorded the least count. This could be attributed to the variation in density of human population activities taking place before and during sampling time as well as the variation of ventilation conditions. These findings do agree with earlier reports by Graduenzet al., 2005, Wamedoet al., 2012. However, there was a slight significant difference between the morning and the evening counts, with an observable increase in the morning counts over the evening counts. This difference could be attributed to the fact that there was less ventilation in the morning due to the shutdown of the doors and windows arising from the previous day human activities. This finding is in agreement with the work done by Hayleeyesus and Manaye, 2014 where the microbial load was more in the morning compare to evening. Another determinant factor in the characteristics of microbial load in enclosed air that was not taken into consideration in this study is atmospheric conditions. This could have played an important role in the determination of internal air quality. The both lecture halls in both weeks recorded the least microbial concentration. In lecture hall I, the bacterial count ranged from $4-86 \mathrm{cfu} / \mathrm{m} 3$ while the fungal count ranged from $6-48 \mathrm{cfu} / \mathrm{m} 3$. While the lecture hall II 
recorded a bacterial count of $5-93 \mathrm{cfu} / \mathrm{m}^{3}$, the fungal count ranged from $10-52 \mathrm{cfu} / \mathrm{m}^{3}$. The female hostel in the both weeks had the highest microbial concentration with the bacterial count ranging from $75-440 \mathrm{cfu} / \mathrm{m} 3 \mathrm{and}$ the fungal count was $10-57 \mathrm{cfu} / \mathrm{m}^{3}$. However, the bacteria and fungi counts were found to be higher in the morning than in the evenings. The bacterial counts in sickbay, administrative block, canteen, library and laboratory ranged between $25-100 \mathrm{cfu} / \mathrm{m}^{3}, 15-76 \mathrm{cfu} / \mathrm{m}^{3}, 25-72 \mathrm{cfu} / \mathrm{m}^{3}, 12-100 \mathrm{cfu} / \mathrm{m}^{3}$ and $9-73 \mathrm{cfu} / \mathrm{m}^{3}$ respectively. Similarly, the fungal counts in sickbay, administrative block, canteen, library and laboratory ranged between $6-30 \mathrm{cfu} / \mathrm{m}^{3}, 5-53 \mathrm{cfu} / \mathrm{m}^{3}, 3-50 \mathrm{cfu} / \mathrm{m}^{3}, 4-23 \mathrm{cfu} / \mathrm{m}^{3}$ and $4-45 \mathrm{cfu} / \mathrm{m}^{3}$. The nature/type of activity that holds in the respective sampling locations also contributed to the characteristics difference in the microbial load during this study. As shown from the results, female hostels and lecture halls had high levels of bacteria and fungi as opposed to less populated offices and libraries. This was observed by StryjakowskaSekulska et al., 2007 who recorded an elevated amount in bacterial load in lecture halls at the start of the session. He also reported the importance of ventilation in the determination of indoor air quality. In the study, a well-ventilated lecture room showed a reduced amount of moulds in the afternoon when compared to other investigated spaces. This is another important aspect of the study that can be taken into consideration for future research; including the frequency and number or personnel in the investigated open space. The bacterial genera and species isolated and characterized from all sample were Micrococcusluteus, Klebsiellapneumonia, Micrococcus sp., Staphylococcusepidermidis, Serratiamarcensces, Streptococcuspyogenes, Bacillussubtilis, Pseudomonasaeruginosa, Staphylococcusaureus, Proteusmirabilis and Escherichiacoli; while the fungal genera and species isolated and characterized were Neurospora sp., Rhizopus sp., Penicillium sp., Candida sp., Fusarium sp. Aspergillusniger, Alternaria sp.,AspergillusfumigatusandCladosporiumcladosporoides.Results of this research showed that the most common fungi were moulds from the genera Aspergillusniger(29\%). Similar findings was also reported by Udochukwuet al., 2015, who recorded the abundance of fungi species of Aspergillus (52.3\%), who also reported the common genera of fungi frequently isolated from the hospital air as Aspergillus, Alternaria and Penicillium. Meanwhile, the least percentage frequency (4\%) of fungi species was recorded as Candida sp. The study of airborne fungal spores is important to understand the dissemination, spread, and movement of the microbes, particularly the pathogenic ones in the atmosphere (Udochukwuet al., 2015). Thus, it can be posited from this investigation that occupants within the investigated enclosed environment are frequently been exposed to health hazards associated with Aspergillus infections. Therefore, students may suffer from (if not controlled) different respiratory diseases. Further studies will be necessary to determine which enclosed space within the school environment contributes a higher amount of a specific microbial species. On the other hand, Staphylococcus aureusrecorded the highest percentage frequency (27\%) of bacteria isolated while Sarretiamarcensces had the least percentage frequency (4\%) of bacteria isolated.

\section{References}

[1]. Awosika, S. A., Olajubu, F. A. and Amusa, N. A. (2012).Microbiological assessment ofindoor air of a teaching hospital in Nigeria.Asian Pacific Journal of Tropical Biomedicine2(6): 465 - 468.

[2]. Chessbrough, M. (1991).Medical laboratory manual for tropical countries. Cambridge University Press UK Pp508-511.

[3]. Dumała, S. M. and Dudzińska, M. R. (2013).Microbiological Indoor Air Quality in Polish Schools.Annual Set The Environment Protection15: 231-244.

[4]. Graudenz, G. S., Oliveira, C. H., Tribess, A., Mendes, C. Jr., Latorre, M. R. and Kalil, J. (2005). Association of air conditioning with respiratory symptoms in office workers in tropical climate. Indoor Air15: 62-66.

[5]. Hayleeyesus, S. F. and Manaye, A. M. (2014).Microbiological Quality of Indoor Air in University Libraries'..Asian Pacific Journal of Tropical Biomedicine. 4(Supplementary 1): S312-S317

[6]. Kalwasińska, A., Burkowska, A. and Wilk, I. (2012).Microbial air contamination in indoor environment of the university library.Annual Agricultural Environment Medicine19(1): 25-29.

[7]. Sneath P.H.A., Mair N.S, Sharpe M. E. and Holt J.G., (1986).Bergey's Manual of Systemic Bacteriology.The Williams \& Wilkins Co.,Baltimore2: 1325-1329

[8]. Soto, T., Murcia, R. M. G., Franco, A., Vicente-Soler, J., Cansado, J. and Gacto, M. (2009).Indoor airborne microbial load in a Spanishuniversity (University of Murcia, Spain). Anales de Biología31: 109-115.

[9]. Stryjakowska-Sekulska, M.,Piotraszewska-Pająk,A.,Szyszka,A.,Nowicki, M. and Filipiak, M. (2007).Microbiological Quality of Indoor Air in University Rooms.PolishJournal of Environmental Studies16(4): 623-632.

[10]. Udochukwu, U., Omeje, F. I., Anulude, O .C. and Ogechi, O.K. (2015).Microbiome of enclosed air in selected dormitories in University of Port Harcourt.AmericanJournal of Research Communication3(5): 217-224.

[11]. Wamedo, S.A., Ede, P.N., and Chuku, A.,(2012).Interaction between building design and indoor airborne microbial load in Nigeria.AsianJournal Biological Science 5: 183-191. 